\title{
PENERAPAN SISTEM PENILAIAN BERBASIS PENALTI UNTUK MEMBENTUK KARAKTER JUJUR, MANDIRI, DAN TANGGUNG JAWAB SISWA SMA DI DAERAH KHUSUS IBUKOTA JAKARTA
}

\author{
Erdawaty Kamaruddin \\ Program Studi Pendidikan Teknik Informatika dan Komputer, \\ Fakultas Teknik, Universitas Negeri Jakarta \\ Jalan Rawamangun Muka - Jakarta Timur 13220 \\ email: erda_kamaruddin@unj.ac.id
}

\begin{abstract}
ABSTRAK
Penelitian ini menggunakan metode deskriptif dengan memaparkan peristiwa aktual, tidak menjelaskan hubungan namun dapat digunakan sebagai landasan untuk penelitian eksplanatif (korelasional). Tujuan penelitian ini adalah untuk menemukan bukti empirik tentang penerapan sistem penilaian berbasis penalti dalam membentuk karakter jujur, mandiri, dan tanggung jawab siswa SMA di Daerah Khusus Ibukota Jakarta. Instrumen penelitian berupa tes obyektif pilihan ganda Matematika kelas XI IPA. Butir tes disusun dengan memperhatikan tahap perkembangan kognitif siswa agar dapat mengukur kemampuan siswa yang sesungguhnya. Hasil penelitian menunjukkan bahwa hanya 1,714 \% siswa memperoleh sekor tidak wajar dan 98,286 \% memperoleh sekor wajar, bahkan $42 \%$ di antaranya medapatkan sekor sangat wajar. Sekor dinyatakan wajar bila sekor yang diperoleh sesuai dengan kemampuan siswa yang sesungguhnya. Sekor yang wajar dapat merefleksikan potensi siswa yang sesungguhnya, dan mengindikasikan bahwa dalam memperoleh sekor tersebut siswa mengerjakan seluruh butir soal dengan jujur, mandiri, dan penuh tanggung jawab. Dengan demikian dapat disimpulkan bahwa penerapan sistem penilaian berbasis penalti dapat membentuk karakter jujur, mandiri, dan tanggung jawab siswa SMA di Daerah Khusus Ibukota Jakarta.
\end{abstract}

Kata Kunci: sistem penilaian berbasis penalti, jujur, mandiri, tanggung jawab.

\section{PENDAHULUAN}

\section{Latar Belakang}

Fenomena ketidakjujuran sudah sangat merajalela di Indonesia, bahkan sudah menyebar luas bagaikan jamur di seluruh lapisan masyarakat. Sangat disayangkan bahwa fenomena ini juga sudah masuk ke dalam dunia pendidikan yang seharusnya justru merupakan wadah untuk mencetak generasi muda penerus bangsa yang bermoral, jujur, dan berjiwa Pancasila.
Contoh sederhana dalam proses pembelajaran adalah budaya mencontek pada saat ujian berlangsung dengan alasan untuk menghindari kegagalan dan meraih nilai yang memuaskan. Namun ironinya, tidak ada yang merasa bersalah terhadap kondisi seperti ini. Apabila moral ini terus dipelihara maka bukan tidak mungkin ketidakjujuran akan menjadi kepribadian para siswa, dan menjadi budaya yang amat sulit dihilangkan. 
Mulai dari sekarang biasakan pola hidup jujur, karena "Jujur itu Hebat".(student.cnnindonesia.com)

Mandiri, menurut Kamus Besar Bahasa Indonesia berarti hal atau keadaan seseorang yang dapat berdiri sendiri tanpa bergantung pada orang lain. Seseorang yang mandiri adalah orang yang percaya diri akan kemampuan dan memiliki prinsip dalam hidupnya sehingga akan cukup mampu melakukan aktivitas apapun dalam hidupnya tanpa harus bergantung pada orang lain. Faktor internal yang mempengaruhi kemandirian belajar siswa adalah disiplin, percaya diri, motivasi, inisiatif, dan tanggung jawab.

Tanggung jawab adalah kesadaran manusia akan tingkah laku atau perbuatan yang disengaja maupun yang tidak disengaja. Tanggung jawab juga berarti berbuat sebagai perwujudan kesadaran akan kewajibannya. Menurut Kamus Besar Bahasa Indonesia bertanggung jawab adalah: berkewajiban menanggung, memikul jawab, menanggung segala sesuatunya, atau memberikan jawab dan menanggung akibatnya. Langkah yang harus dilakukan untuk membentuk kebiasaan agar dapat bertanggung jawab, antara lain adalah:

(1) mulailah dari hal-hal kecil, buatlah daftar berisi hal-hal yang menuntut tanggung jawab, mulailah dari yang paling mudah dahulu baru lakukan yang lain, (3) bantulah orang lain, (4) jangan suka mengulur-ulur waktu, (5) ambillah inisiatif, (6) jadilah orang yang mampu menentukan tujuan yang bersifat realistis, (7) buatlah jadwal rutinitas harian, bertanggungjawablah atas apa yang dimiliki, (9) berusahalah datang lebih awal di mana saja. (id.wikihow.com)

Sistem penilaian adalah cara yang digunakan untuk memperoleh sekor dari suatu tes. Ada berbagai sistem penilaian pada tes obyektif pilihan ganda, salah satu diantaranya adalah sistem penilaian berbasis penalti, yaitu: cara perolehan sekor pada tes obyektif pilihan ganda melalui penjumlahan sekor pada butir soal dengan jawaban yang benar dan memberikan hukuman atau penalti berupa pengurangan sekor pada butir soal dengan jawaban yang salah. Sistem penilaian berbasis penalti digunakan untuk menetralisir kemungkinan jawaban siswa merupakan hasil tebakan, karena tes bertujuan untuk mengetahui seberapa besar potensi yang ada pada diri siswa, bukan untuk mengetahui kelihaian siswa dalam menerka jawaban.

Ketidakwajaran sekor terjadi ketika siswa berhasil menjawab dengan benar butir yang sukar dan tidak dapat 
menjawab dengan benar butir yang mudah. Akibat dari ketidakwajaran sekor adalah siswa dapat saja memperoleh sekor yang jauh lebih rendah dari sekor yang seharusnya diperoleh berdasarkan kemampuannya, begitu juga sebaliknya, siswa dapat saja memperoleh sekor yang jauh di atas kemampuannya yang sebenarnya. ( Dali S. Naga: 1992:473)

Ketidakwajaran sekor sangat mungkin terjadi pada tes obyektif pilihan ganda, dan pendeteksian ketidakwajaran sekor dapat dilakukan melalui perhitungan suatu indeks yang dikenal sebagai indeks kewajaran sekor. Indeks kewajaran sekor adalah angka yang menunjukkan seberapa besar sekor yang diperoleh siswa dapat menggambarkan kemampuan sesungguhnya dari siswa tersebut. Makin tinggi indeks kewajaran sekor, maka makin cocok sekor siswa tersebut dengan sekor kelompok siswa sehingga makin wajar sekor siswa tersebut. ( Dali S. Naga: 1992:444)

Uraian latar belakang masalah di atas memberikan indikasi bahwa terdapat permasalahan yang sangat mendasar sehubungan dengan pembentukan karakter jujur, mandiri, dan tanggung jawab siswa, yaitu: masalah kejujuran, kemandirian, dan tanggung jawab siswa dalam menjawab butir soal ujian. Kejujuran, kemandirian, dan tanggung jawab siswa antara lain dapat terlihat pada saat menjawab butir soal tes obyektif pilihan ganda karena jawaban tes obyektif pilihan ganda banyak memberikan kesempatan kepada siswa untuk berspekulasi dalam menjawab setiap butir soal.

\section{Perumusan Masalah}

Berdasarkan hal tersebut, maka masalah dalam penelitian ini dapat dirumuskan sebagai berikut: "Apakah penerapan sistem penilaian berbasis penalti dapat membentuk karakter jujur, mandiri, dan tanggung jawab siswa SMA di Daerah Khusus Ibukota Jakarta?“

\section{Tujuan Penelitian}

Tujuan penelitian ini adalah untuk memperoleh data empirik tentang penerapan sistem penilaian berbasis penalti dalam membentuk karakter jujur, mandiri, dan tanggung jawab siswa SMA di Daerah Khusus Ibukota Jakarta.

\section{KAJIAN TEORI}

Karakter Jujur, Mandiri, dan Tanggung Jawab

Kementerian Pendidikan dan Kebudayaan Republik Indonesia saat ini tengah menggalakkan pendidikan 
budaya dan karakter bangsa dengan nilai-nilai yang bersumber pada delapan belas nilai budaya dan karakter bangsa. Karakter jujur, mandiri, dan tanggung jawab merupakan sebagian dari nilai budaya dan karakter bangsa yang selalu didengungkan oleh pemerintah dan harus dibentuk pada proses pembelajaran dalam pelaksanaan Kurikulum 2013.

Jujur merupakan salah satu sifat dasar manusia yang cukup sulit untuk diterapkan. Kata "Jujur" digunakan untuk menyatakan sikap seseorang yang bila memberikan informasi tentang gambaran kejadian yang pernah dihadapinya sesuai dengan realitas kejadian tersebut tanpa ada "perubahan" sama sekali. Dalam agama Islam sikap seperti inilah yang dinamakan shiddiq, di mana jujur itu bernilai tak terhingga. Seseorang dapat jujur, baik bila sedang diawasi maupun tidak sedang diawasi. Kejujuran dalam Kamus Besar Bahasa Indonesia adalah perbuatan yang lurus hati, tulus, dan ikhlas. Artinya, kejujuran adalah nilai kebaikan sebagai sifat positif yang akan diterima semua orang di manapun dan kapanpun berada. Kejujuran adalah kunci untuk membangun kepercayaan. Sebaliknya, berbohong dapat menghancurkan kehidupan seseorang.

Derajat kejujuran yang paling tinggi adalah as-shiddiqiyyah, yaitu: ketundukan yang sempurna kepada Rasûlullâh Shallallahu 'Alaihi Wasallam dan keikhlasan yang sempurna kepada Allâh Azza Wa Jalla. Di antara tanda kejujuran itu adalah tenangnya hati dan ketenteraman, sebaliknya di antara tanda kedustaan adalah kebimbangan hati dan keraguraguan. Ketahuilah, bahwa kata "jujur" dapat digunakan untuk beberapa makna, sebagai berikut: (1) "Jujur dalam perkataan", (2) "Jujur dalam niat dan keinginan", (3) "Jujur dalam tekad dan jujur memenuhinya", (4) "Jujur dalam amal perbuatan", dan 5) "Jujur dalam kedudukan agama”. Ini adalah derajat tertinggi, seperti jujur dalam takut dan berharap, zuhûd dan ridha, cinta dan tawakkal (kepada Allâh Azza Wa Jalla). Karena perkara-perkara ini memiliki dasar pijakan, memiliki tujuan-tujuan juga hakikat (almanhaj.or.id)

Kehidupan manusia saat ini makin dihadapkan dengan permasalahan kompleks. Keadaan ini menuntut setiap individu untuk mampu memecahkan permasalahan yang dihadapi tanpa harus tergantung pada orang lain dan berani menentukan sikap yang tepat. Salah satu aspek penting yang diperlukan adalah mandiri dalam bersikap dan bertindak. Mandiri berarti kemampuan seseorang untuk melakukan, memikirkan, dan 
merasakan sesuatu, untuk mengatasi masalah, bersaing, mengerjakan tugas, dan mengambil keputusan dengan tingkat kepercayaan diri yang tinggi, bertanggung jawab, serta tidak bergantung pada bantuan orang lain. Kemandirian merupakan aspek yang berkembang dalam diri setiap orang, yang bentuknya sangat beragam, pada tiap orang yang berbeda, tergantung pada proses perkembangan dan proses belajar yang dialami masing-masing orang. Karena itu kemandirian mengandung pengertian: (1) memiliki suatu penghayatan/semangat untuk menjadi lebih baik dan percaya diri, (2) mengelola pikiran untuk menelaah masalah dan mengambil keputusan untuk bertindak, (3) disiplin dan tanggung jawab, dan (4) tidak bergantung pada orang lain.

(yangdimaksuddengan.blogspot.co.id)

Dari beberapa pendapat para ahli di atas dapat diambil kesimpulan bahwa kemandirian merupakan sikap yang memungkinkan seseorang untuk bertindak bebas, melakukan sesuatu atas dorongan diri sendiri dan kemampuan mengatur diri sendiri, sesuai dengan hak dan kewajibannya sehingga dapat menyelesaikan sendiri masalah-masalah yang dihadapi tanpa meminta bantuan atau tergantung pada orang lain dan dapat bertanggung jawab terhadap segala keputusan yang telah diambil melalui berbagai pertimbangan sebelumnya.

Tanggung jawab adalah keadaan wajib menanggung segala sesuatunya. Bertanggung jawab menurut Kamus Besar Bahasa Indonesia adalah berkewajiban menanggung, memikul jawab, menanggung segala sesuatunya, atau memberikan jawab dan menanggung akibatnya. Tanggung jawab adalah kesadaran manusia akan tingkah laku atau perbuatan yang disengaja maupun yang tidak di sengaja. Tanggung jawab juga berarti berbuat sebagai perwujudan kesadaran akan kewajibannya.

Tanggung jawab itu bersifat kodrati, artinya sudah menjadi bagian kehidupan manusia, bahwa setiap manusia pasti dibebani dengan tanggung jawab. Apabila tidak mau bertanggung jawab, maka ada pihak lain yang memaksakan tanggung jawab itu. Dengan demikian tanggung jawab itu dapat dilihat dari dua sisi, yaitu: dari sisi pihak yang berbuat dan dari sisi kepentingan pihak lain. Apabila dikaji tanggung jawab itu adalah kewajiban yang harus dipikul sebagai akibat dari perbuatan pihak yang berbuat. Tanggung jawab itu dapat dibedakan menurut keadaan manusia atau hubungan yang dibuatnya. Atas dasar ini, lalu dikenal beberapa jenis 
tanggung jawab, yaitu: (a) tanggung jawab terhadap diri sendiri, (b) tanggung jawab terhadap keluarga, (c) tanggung jawab terhadap masyarakat, (d) tanggung jawab terhadap bangsa dan negara, dan (e) tanggung jawab terhadap Allah SWT. (triicecsfabregas.blogspot.com)

Dalam proses mendidik anak agar bertanggung jawab, dibutuhkan dua faktor penting, yaitu: rasa percaya diri dan disiplin. Selanjutnya, terdapat empat faktor yang dapat menghambat terbentuknya karakter bertanggung jawab pada diri seorang anak, yaitu: (1) orang tua yang mengambil alih tanggung jawab anak, (2) orang tua yang menilai segala sesuatu ditinjau dari hasil yang sempurna, (3) orang tua yang menilai dari segi efesiensi dan efektivitas, dan (4) orang tua yang sangat mengasihi anaknya sehingga cenderung over-protective. (www.telaga.org)

Beberapa hal yang dapat dilakukan untuk mengembangkan tanggung jawab anak, adalah sebagai berikut: (1) berilah kesempatan kepada anak untuk melakukan sendiri apa yang ingin dilakukan selama itu tidak membahayakan dirinya, sambil tetap diberikan pengarahan, pemantauan, dan pendampingan, (2) berilah penghargaan berupa pujian dan dorongan atas apa yang sudah diusahakannya. Jangan terfokus pada kekurangannya, tetapi pada usaha dan apa yang sudah dikerjakannya, (3) berilah tugas yang sesuai dengan kemampuan anak. Jangan menuntut anak melakukan sesuatu melampaui kemampuannya, (4) libatkan anak dalam berbagai tugas yang menyangkut kepentingannya pribadi maupun kepentingan keluarga, dan (5) berilah ganjaran/imbalan yang sesuai dengan perbuatan yang dilakukan. Ini termasuk salah satu bentuk disiplin. (www.telaga.org)

\section{Sistem Penilaian Berbasis Penalti}

Proses pengukuran dalam dunia pendidikan menghasilkan data kuantitatif dan dilakukan secara obyektif dengan menggunakan alat ukur berupa instrumen tes maupun non tes. Hasil dari pengukuran adalah sekor yang diperoleh dari respon siswa terhadap stimulus yang diberikan, dengan demikian sekor dapat menggambarkan kemampuan siswa. Menurut Crocker dan Algina sekor adalah jumlah jawaban benar dari siswa, di mana jawaban yang benar mendapat sekor satu dan jawaban yang salah mendapat sekor nol. (Linda Crocker:1986:399) Sedangkan Arikunto berpendapat bahwa sekor adalah hasil pekerjaan mensekor yang 
diperoleh dengan menjumlahkan angka-angka bagi setiap soal tes yang dijawab betul oleh siswa. (Suharsimi Arikunto:2012:271) Selanjutnya, Naga mengemukakan bahwa sekor adalah bilangan yang diberikan kepada atribut dari subyek yang diukur. ${ }^{1} \mathrm{Hal}$ senada disampaikan oleh Purwanto dalam pernyataannya bahwa sekor adalah bilangan yang diterakan atas jawaban yang diberikan oleh siswa yang memberi petunjuk mengenai perolehan hasil belajar siswa tersebut. Jadi sekor yang didapat siswa mencerminkan perolehan hasil belajar siswa tersebut. ( Dali S. Naga: 1992 : 44)

Pendapat lain disampaikan oleh Sudijono yang menjelaskan bahwa sekor adalah hasil pekerjaan menyekor atau memberikan angka dengan jalan menjumlahkan angkaangka bagi setiap butir soal yang dijawab benar, dengan memperhitungkan bobot jawaban benarnya.

Setelah membahas sekor, maka selanjutnya akan diuraikan mengenai pensekoran. Djaali dan Muljono mendeskripsikan pensekoran sebagai suatu proses pengubahan jawaban instrumen menjadi angka-angka yang merupakan nilai kuantitatif dari suatu jawaban terhadap item dalam instrumen. Jadi pensekoran merupakan kuantifikasi terhadap jawaban responden. (Djaali dan Pudji Muljono:2008:101) Pada dasarnya pensekoran adalah suatu proses pengubahan jawaban tes menjadi angka. Angka-angka hasil pensekoran itu kemudian diubah menjadi nilai-nilai melalui suatu proses pengolahan tertentu. Nilai-nilai tersebut dapat dinyatakan dalam bentuk angka atau dengan menggunakan huruf. Pensekoran dapat dilakukan pada tes uraian maupun tes obyektif. Pensekoran pada tes uraian dilakukan dengan cara pemberian bobot kepada setiap butir soal menurut tingkat kesukarannya, sedangkan pensekoran pada tes obyektif secara umum berbentuk pensekoran dikotomi, yaitu: setiap jawaban benar diberi sekor satu dan setiap jawaban salah diberi sekor nol, total sekor diperoleh dengan menjumlahkan sekor dari semua butir soal. Menurut Purwanto pensekoran adalah proses pengubahan prestasi menjadi angka. (Purwanto:73) Pensekoran harus dilakukan secara obyektif. Artinya, apabila pensekoran dilakukan oleh dua orang atau lebih yang sama tingkat kompetensinya atau jika orang yang sama mengulangi proses pensekoran, akan dihasilkan sekor yang sama. 
Proses pengolahan angka hasil pensekoran menjadi nilai harus dilakukan melalui berbagai sistem penilaian agar diperoleh nilai yang akurat dan dapat menggambarkan kemampuan siswa yang sesungguhnya. Salah satu sistem penilaian yang dapat digunakan adalah sistem penilaian berbasis penalti, yaitu: sistem penilaian dengan memberikan penalti atau hukuman, artinya, cara perolehan sekor pada tes obyektif pilihan ganda melalui penjumlahan sekor pada butir soal dengan jawaban yang benar dan memberikan hukuman atau penalti berupa pengurangan sekor pada butir soal dengan jawaban yang salah. Sistem penilaian berbasis penalti digunakan untuk menetralisir kemungkinan jawaban siswa merupakan hasil tebakan, karena tes bertujuan untuk mengetahui seberapa besar potensi yang ada pada diri siswa, bukan untuk mengetahui kelihaian siswa dalam menerka jawaban.

Menurut Naga, penalti adalah hukuman pengurangan nilai pada sekor responden. Salah satu alasan untuk penalti terletak pada ujian pilihan ganda. Jika siswa tidak memahami pertanyaan pada butir soal maka siswa tersebut dapat menerka. Terkaan ini dapat menghasilkan jawaban salah namun dapat juga menghasilkan jawaban betul. (Dali. S. Naga: 2012
: 88) Terkaan ini diberi penalti dengan mengurangi sekor. Indikator terkaan adalah jawaban salah sehingga jawaban salah dikenakan penalti, artinya jawaban benar diberi sekor 1 , tidak menjawab diberi sekor 0 , dan jawaban salah diberi sekor penalti. (http://staffsite.gunadarma.ac.id) Guilford juga menyatakan bahwa "untuk menghindari siswa menebak jawaban, maka dilakukan pensekoran dengan cara penalti". Besarnya hukuman tergantung dari jumlah opsi pada tes obyektif pilihan ganda. ( J.P. Guilford :1982:447) Hal senada dikemukakan oleh Purwanto yang menggunakan istilah correction for guessing atau sistem denda untuk menyebutkan model pensekoran dengan hukuman. (M. Ngalim Purwanto:2009:45)

Pada sistem penilaian berbasis penalti, siswa akan lebih berhati-hati dalam menjawab butir soal yang dianggap sukar, bahkan cenderung tidak menjawab butir soal yang tidak dikuasainya untuk mencegah hukuman berupa pengurangan sekor. Namun untuk butir soal tertentu, tebakan murnipun akan tetap dilakukan, sehingga kemungkinan terjadinya ketidakwajaran sekor akan tetap ada. Ketidakwajaran sekor adalah sekor yang tidak sesuai dengan kemampuan siswa walaupun semua butir soal sudah 
baik. (Dali S. Naga:2012:47) Akibat dari ketidakwajaran sekor adalah siswa dapat saja memperoleh sekor yang jauh lebih rendah dari sekor yang seharusnya diperoleh berdasarkan kemampuannya, begitu juga sebaliknya, siswa dapat saja memperoleh sekor yang jauh di atas kemampuannya yang sebenarnya. Ketidakwajaran sekor merupakan selisih antara pengetahuan sebenarnya yang dimiliki siswa dengan pengetahuan yang ditunjukkan oleh sekor yang diperolehnya setelah mengerjakan tes. Selanjutnya dapat dikemukakan bahwa ketidakwajaran sekor adalah ketimpangan sekor yang bersumber pada siswa, di mana siswa yang biasanya mampu ternyata memperoleh sekor rendah dan sebaliknya, siswa yang biasanya kurang mampu ternyata memperoleh sekor tinggi. Ketidakwajaran sekor sering terjadi pada tes obyektif pilihan ganda. Untuk mengatasi kekeliruan makna dari sekor tidak wajar yang diperoleh siswa, maka perlu pendeteksian ketidakwajaran sekor. Ketidakwajaran sekor dinyatakan dalam bentuk indeks, dengan demikian pendeteksian ketidakwajaran sekor dapat dilakukan melalui perhitungan suatu indeks yang dikenal sebagai indeks kewajaran sekor.
Indeks kewajaran sekor adalah angka yang menunjukkan seberapa besar sekor yang diperoleh siswa dapat menggambarkan kemampuan sebenarnya dari siswa tersebut. Makin tinggi indeks kewajaran, maka makin cocok sekor siswa tersebut dengan sekor kelompok siswa sehingga makin wajar sekor siswa tersebut. Sebaliknya, makin rendah atau bahkan bernilai negatif indeks kewajaran, maka makin tidak cocok sekor siswa tersebut dengan sekor kelompok siswa sehingga makin tidak wajar sekor siswa tersebut. Perhitungan indeks kewajaran sekor pada teori pengukuran klasik dapat dilakukan dengan menggunakan berbagai metoda, dan dalam penelitian ini yang akan dikaji adalah perhitungan indeks kewajaran sekor menggunakan metoda Donlon dan Fisher. Sesuai dengan namanya, metoda Donlon dan Fisher diperkenalkan oleh T.F. Donlon dan F.E. Fisher pada tahun 1968. (Dali S. Naga:2012:394) Pendeteksian ketidakwajaran sekor pada metoda Donlon dan Fisher dihitung melalui korelasi biserial peserta, dengan cara mengkorelasikan secara biserial pola kesukaran butir yang dilihat oleh satu siswa dengan pola kesukaran butir yang dilihat oleh kelompok siswa dan menyatakan korelasi biserial itu sebagai indeks kewajaran sekor dari siswa. Rumus indeks kewajaran 
Donlon dan Fisher adalah sebagai berikut: (Dali S. Naga:2012:450)

$$
\rho_{i b i s}=\frac{\mu_{\Delta t}-\mu_{\Delta p}}{\sigma_{\Delta}} \frac{p_{i t}}{y}
$$

\section{METODE PENELITIAN}

\section{Waktu dan Tempat Penelitian}

Penelitian ini dilaksanakan di enam SMA yang berada di lima wilayah Provinsi DKI Jakarta, yaitu: di SMAN 51 Jakarta Timur, SMAN 3 Jakarta Selatan, SMAN 1 Jakarta Pusat, SMAN 78 dan SMAN 112 Jakarta Barat, serta SMAN 52 Jakarta Utara. Subyek penelitian adalah siswa SMA kelas XI IPA.

\section{Teknik Pengumpulan Data}

Sekor responden dalam penelitian ini merupakan data primer, karena diperoleh langsung dari responden yang dipilih sebagai sampel dengan menggunakan instrumen penelitian berupa perangkat tes obyektif pilihan ganda untuk mata pelajaran Matematika bagi siswa SMA kelas XI IPA. Sebelum instrumen penelitian digunakan, terlebih dahulu dilakukan ujicoba instrumen penelitian untuk perbaikan dan validasi serta perhitungan reliabilitas hasil ukur. Lalu instrumen penelitian diberikan kepada kelompok responden.
Setelah pengumpulan data selesai, semua data diperiksa, diseleksi, dan ditabulasi untuk mempermudah pengolahan dan analisis data selanjutnya. Langkah-langkah pengumpulan data adalah sebagai berikut: (1) pengelompokan responden pada masing-masing sekolah, (2) pemberian instrumen penelitian kepada seluruh responden, (3) Pengkoreksian lembar jawaban menggunakan perangkat lunak Anates, pendeteksian ketidakwajaran sekor menggunakan metoda Donlon dan Fisher, (5) analisis deskripsi data responden, (6) analisis deskripsi data sekor, (7) analisis deskripsi data indeks kewajaran sekor, (7) uji normalitas, dan (8) analisis hasil penelitian.

\section{Metode Penelitian}

Penelitian ini menggunakan metode deskriptif dengan memaparkan kejadian atau peristiwa aktual, tidak mencari atau menjelaskan hubungan, dan tidak menguji hipotesis atau membuat prediksi, namun dapat digunakan sebagai landasan untuk penelitian eksplanatif (korelasional). Penelitian deskriptif melukiskan variabel demi variabel, satu demi satu dan mengumpulkan data secara univariat. Penelitian deskriptif memandang fenomena sebagai sekumpulan variabel bukan sebagai 
hubungan antarvariabel dan mengungkapkan fenomena tersebut dengan pertanyaan what dan how. Tujuan umum dari penelitian deskriptif adalah untuk melukiskan secara sistematis fakta atau karakteristik populasi tertentu atau bidang tertentu, sedangkan tujuan khusus dari penelitian deskriptif ini adalah untuk: (1) mengumpulkan informasi aktual secara rinci yang melukiskan gejala yang ada, (2) mengidentifikasi masalah atau memeriksa kondisi atau praktikpraktik yang berlaku, dan (3) membuat perbandingan atau evaluasi. Analisis data dalam penelitian ini dilakukan dengan bantuan teknik statistik (statistik deskriptif). Variabel bebas yang diteliti adalah sistem penilaian berbasis penalti, sedangkan variabel terikat yang diteliti adalah sikap jujur, mandiri, dan tanggung jawab.

\section{HASIL PENELITIAN DAN PEMBAHASAN}

\section{Hasil Ujicoba Instrumen Penelitian}

Penelitian ini mengikutsertakan tiga ratus lima puluh siswa SMA di seluruh wilayah DKI Jakarta. Data penelitian diperoleh dari hasil jawaban siswa terhadap instrumen penelitian yang diujikan di sekolah masing-masing. Instrumen penelitian berupa tes obyektif pilihan ganda dengan menerapkan sistem penilaian berbasis penalti untuk mata pelajaran Matematika kelas XI IPA sudah melalui uji pakar dan sudah diujicobakan terlebih dahulu sebelum pengambilan data dilakukan. Hasil ujicoba instrumen penelitian menunjukkan 30 butir soal dinyatakan valid. Uji validitas butir dihitung dengan menggunakan rumus koefisien korelasi point biserial karena butir instrumen penelitian berbentuk dikotomi. Dari 30 butir soal yang dinyatakan valid, kemudian dihitung nilai-nilai yang diperlukan untuk perhitungan reliabilitas instrumen menggunakan rumus KuderRichardson 20, dan dari hasil perhitungan diperoleh nilai koefisien reliabilitas sebesar 0,9325. Kriteria yang digunakan adalah, apabila nilai koefisien reliabilitas lebih besar atau sama dengan 0,90 maka instrumen penelitian dinyatakan reliabel, artinya, instrumen penelitian ini sudah memiliki tingkat kepercayaan yang tinggi dan dapat dipakai untuk menjaring data penelitian.

\section{Deskripsi Data Hasil Penelitian}

Deskripsi data hasil penelitian berdasarkan sekor responden yang diperoleh dari hasil pengukuran menggunakan instrumen tes obyektif pilihan ganda lima opsi pada sistem 
penilaian berbasis penalti dirangkum dalam Tabel 1 berikut ini:

Tabel 1. Rangkuman Karakteristik Sekor Responden pada Tes Obyektif Pilihan Ganda Lima Opsi dengan Menerapkan Sistem Penilaian Berbasis Penalti

\begin{tabular}{|c|c|c|c|c|c|c|c|}
\hline Kelompok & Minimum & Maksimum & Rata2 & Median & Modus & Variansi & Simp.Baku \\
\hline SPS5 & 13 & 26 & 20,0743 & 20,0846 & 21,7736 & 7,0833 & 2,6614 \\
\hline
\end{tabular}

Gambar 1. menunjukkan posisi relatif sekor rata-rata responden terhadap sekor lainnya. Pada gambar tersebut terlihat bahwa posisi sekor rata-rata berada di bawah median $\left(\mu_{\text {SPS5 }}\right.$ $<$ median). Hal ini memberikan indikasi bahwa sekor responden pada tes obyektif pilihan ganda lima opsi dengan menerapkan sistem penilaian berbasis penalti cenderung memiliki sekor yang lebih rendah dari median atau dapat dikatakan memiliki kecondongan negatif (negatively skewed).

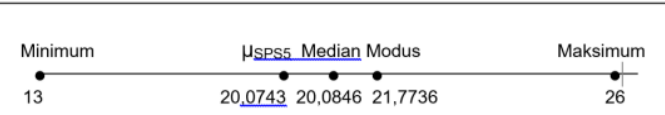

Gambar 1. Posisi Relatif Sekor RataRata Responden pada Tes Obyektif Pilihan Ganda Lima Opsi dengan Menerapkan Sistem Penilaian Berbasis Penalti

Deskripsi data hasil penelitian berdasarkan indeks kewajaran sekor responden yang diperoleh dari hasil pengukuran menggunakan instrumen tes obyektif pilihan ganda lima opsi pada sistem penilaian berbasis penalti dirangkum dalam Tabel 2.

Tabel 2. Rangkuman Karakteristik Indeks Kewajaran Sekor Responden pada Tes Obyektif Pilihan Ganda Lima Opsi dengan Menerapkan Sistem Penilaian Berbasis Penalti

\begin{tabular}{|c|c|c|c|c|c|c|c|}
\hline Kelompok & Minimum & Maksimum & Rata2 & Median & Modus & Variansi & Simp.Baku \\
\hline PS5 & 0,4745 & 0,9976 & 0,7712 & 0,7684 & 0,8084 & 0,0188 & 0,1367 \\
\hline
\end{tabular}

Posisi relatif sekor rata-rata terhadap sekor lainnya dari indeks kewajaran sekor responden pada tes obyektif pilihan ganda lima opsi dengan menerapkan sistem penilaian berbasis penalti terlihat pada Gambar 2. sebagai berikut:

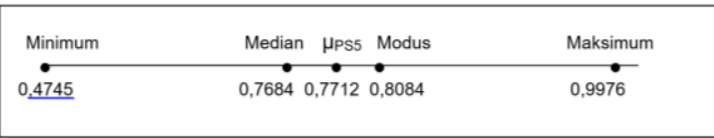

Gambar 2. Posisi Relatif Indeks Kewajaran Sekor Rata-Rata Responden pada Tes Obyektif Pilihan Ganda Lima Opsi dengan Menerapkan Sistem Penilaian Berbasis Penalti

Pada Gambar 2. terlihat bahwa posisi indeks kewajaran sekor rata-rata berada di atas median ( $\mu_{\mathrm{PS} 5}>$ median). Hal ini mengindikasikan bahwa indeks kewajaran sekor responden pada tes obyektif pilihan ganda lima opsi dengan menerapkan sistem penilaian berbasis penalti cenderung memiliki sekor yang lebih tinggi dari median atau dapat dikatakan memiliki kecondongan positif (positively skewed). 


\section{Hasil Penelitian dan Pembahasan}

$\begin{array}{rrrr} & \text { Berbagai temuan penelitian } \\ \text { yang dilakukan secara } & \text { deskriptif }\end{array}$ sebagaimana telah diuraikan, dijadikan sebagai acuan dalam membuat kajian lebih lanjut mengenai penerapan sistem penilaian berbasis penalti dalam membentuk karakter jujur, mandiri, dan tanggung jawab siswa. Kajian utama dalam penelitian ini adalah analisis penerapan sistem penilaian berbasis penalti dalam membentuk karakter jujur, mandiri, dan tanggung jawab siswa SMA di Daerah Khusus Ibukota Jakarta melalui hasil tes obyektif pilihan ganda untuk mata pelajaran Matematika kelas XI IPA. Data penelitian dianalisis menggunakan metoda Donlon dan Fisher dengan menghitung indeks kewajaran sekor melalui korelasi biserial peserta. Koefisien korelasi biserial yang dikenal sebagai indeks kewajaran sekor mengindikasikan tingkat ketidakwajaran sekor responden. Koefisien korelasi biserial yang relatif besar menunjukkan bahwa sekor responden relatif wajar, dan perolehan sekor tersebut dapat menggambarkan kemampuan siswa yang sesungguhnya. Sebaliknya, koefisien korelasi biserial yang relatif kecil menunjukkan bahwa sekor yang diperoleh responden relatif tidak wajar karena perolehan sekor tidak menggambarkan kemampuan siswa yang sesungguhnya. Artinya, ada ketidakcocokan di antara kemampuan siswa dengan sekor yang diperoleh, di mana, karena suatu hal siswa dengan kemampuan rendah memperoleh sekor tinggi dan siswa dengan kemampuan tinggi memperoleh sekor rendah. Jadi, makin tinggi indeks kewajaran, maka makin wajar sekor siswa tersebut. Sebaliknya, makin rendah indeks kewajaran, maka makin tidak wajar sekor siswa tersebut.

Hasil analisis data menunjukkan bahwa 98,286 \% siswa memperoleh indeks kewajaran sekor tinggi. Dalam hal ini sistem penilaian berbasis penalti dapat menghasilkan indeks kewajaran sekor tinggi bagi hampir seluruh responden. Artinya, sistem penilaian berbasis penalti menghasilkan sekor yang wajar. Sekor yang wajar dapat merefleksikan potensi siswa yang sesungguhnya, dan mengindikasikan bahwa dalam memperoleh sekor tersebut siswa mengerjakan seluruh butir soal dengan jujur, mandiri, dan penuh tanggung jawab. Dengan demikian dapat disimpulkan bahwa penerapan sistem penilaian pembelajaran berbasis penalti dapat membentuk karakter jujur, mandiri, dan tanggung jawab siswa 
SMA di Daerah Khusus Ibukota Jakarta.

Karakter jujur, mandiri, dan tanggung jawab yang dikaji dalam penelitian ini dipengaruhi oleh penerapan sistem penilaian yang diberikan. Hal ini memberikan verifikasi bahwa penilaian berbasis penalti dapat membentuk karakter jujur, mandiri, dan tanggung jawab siswa terutama pada saat menjawab butir soal tes obyektif pilihan ganda. Kondisi ini terjadi karena pada sistem penilaian berbasis penalti berlaku pensekoran dengan hukuman atau penalti, yaitu: cara perolehan sekor pada tes obyektif pilihan ganda melalui penjumlahan sekor pada butir soal dengan jawaban yang benar dan memberikan hukuman berupa pengurangan sekor pada butir soal dengan jawaban yang salah. Dengan adanya hukuman berupa pengurangan sekor, maka secara umum pada sistem penilaian berbasis penalti, siswa tidak akan menjawab butir soal yang tidak dikuasainya dan juga tidak akan berusaha mencontek jawaban teman karena menghindar dari resiko pengurangan nilai. Hal ini memberikan indikasi bahwa siswa akan mengerjakan butir soal tes obyektif pilihan ganda itu dengan jujur, mandiri, dan bekerja keras penuh dengan rasa tanggung jawab. Berdasarkan pembahasan di atas, diperoleh generalisasi empiris bahwa penerapan sistem penilaian berbasis penalti dapat membentuk karakter jujur, mandiri, dan tanggung jawab siswa SMA di Daerah Khusus Ibukota Jakarta.

\section{KESIMPULAN}

Berdasarkan hasil penelitian yang telah dikemukakan di dalam deskripsi dan analisis data di atas, diperoleh temuan-temuan sebagai berikut: (1) Pada tes obyektif pilihan ganda terdapat ketidakwajaran sekor responden. Dalam hal ini, dengan penerapan sistem penilaian berbasis penalti, ternyata masih diperoleh sekor responden yang tidak sesuai dengan kemampuan responden yang sesungguhnya, di mana $1,714 \%$ siswa memperoleh indeks kewajaran sekor di bawah 0,5, dan (2) Penerapan sistem penilaian berbasis penalti, dapat menjadi salah satu alternatif untuk membentuk karakter jujur, mandiri, dan tanggung jawab siswa dalam mengerjakan butir soal pilihan ganda. Dalam hal ini, dengan penerapan sistem penilaian berbasis penalti diperoleh 98,286\% siswa memperoleh sekor yang wajar sesuai dengan kemampuan siswa yang sesungguhnya.

$$
\text { Berdasarkan temuan }
$$

tersebut di atas, maka dari hasil 
penelitian ini dapat diambil kesimpulan sebagai berikut: "Penerapan sistem penilaian pembelajaran berbasis penalti dapat membentuk karakter jujur, mandiri, dan tanggung jawab siswa SMA di Daerah Khusus Ibukota Jakarta"

\section{SARAN}

Saran yang dikemukakan dalam membentuk karakter jujur, mandiri, dan tanggung jawab siswa adalah: sebaiknya dalam tes obyektif pilihan ganda digunakan sistem penilaian berbasis penalti, karena dapat menghasilkan sekor yang wajar dan dapat menggambarkan kemampuan siswa yang sesungguhnya.

\section{DAFTAR PUSTAKA}

Arikunto, Suharsimi. Dasar-Dasar Evaluasi Pendidikan. Jakarta: Bumi Aksara, 2012.

Crocker, Linda dan James Algina. Introduction to Classical and Modern Test Theory. Orlando: Holt Rinehart and Winston, Inc., 1986.

Djaali dan Pudji Muljono. Pengukuran dalam Bidang Pendidikan. Jakarta: PT. Gramedia Widiasarana Indonesia, 2008.

Guilford, J.P. Psychometric Methods. New Delhi: Tata-McGraw Hill, 1982.

Naga, Dali S. Pengantar Teori Sekor Pada Pengukuran Pendidikan. Jakarta: Gunadarma, 1992.
Teori Sekor Pada Pengukuran Mental. Jakarta: PT. Nagarani Citrayasa, 2012.

"Sekor Responden." http://staffsite.gunadarma.ac.id ./dali, (Di Akses Tanggal 21 Februari 2012).

Purwanto, M. Ngalim. Prinsip-prinsip dan Teknik Evaluasi Pengajaran. Bandung: PT. Remaja Rosdakarya, 2009.

Purwanto. Evaluasi Hasil Belajar. Yogyakarta: Pustaka Pelajar, 2008.

Sudijono, Anas. Pengantar Evaluasi Pendidikan. Jakarta: PT. Raja Grafindo Persada,1996.

https://almanhaj.or.id/4089-berkatabenar-jujur-dan-jangan-dustabohong. html, diakses tanggal 24 September 2017.

https://id.wikihow.com/MenjadiOrang-yang-BertanggungJawab, diakses tanggal 24 September 2017.

https://student.cnnindonesia.com/eduka si/20170329112807-445203352/ membiasakan-hidupdengan-jujur/, diakses tanggal 24 September 2017.

http://triicecsfabregas.blogspot.com/20 11/11/manusia-dan-tanggungjawab.html, diakses tanggal 24 September 2017.

https://www.telaga.org/artikel/tanggun g-jawab-siapa-takut/, diakses tanggal 24 September 2017.

http://yangdimaksuddengan.blogspot.c o.id/2012/07/apa-yangdimaksud-dengan mandiri. html, diakses tanggal 24 September 2017 